UTILITY: Jurnal IImiah Pendidikan dan Ekonomi

Volume 3, No. 1, Februari 2019: Page 55-66

ISSN 2549-1377 (Print) || ISSN 2549-1385 (Online)

Available online at http://journal.stkipnurulhuda.ac.id/index.php/utility

\title{
PENGARUH PROFESIONALITAS DOSEN DALAM PERKULIAHAN TERHADAP KEPUASAN MAHASISWA ATAS LAYANAN AKADEMIK PADA PROGRAM STUDI PENDIDIKAN EKONOMI STKIP NURUL HUDA SUKARAJA
}

\author{
Pipin Listiani1, Dwi Susanti2, Vovi Sinta3 \\ ${ }^{1,2,3}$ STKIP Nurul Huda OKU Timur \\ *E-mail: *vovisinta@gmail.com
}

\begin{abstract}
Abstrak:Tuntutan dan harapan profesionalisme bagi dosen menjadi kebutuhan mendesak untuk meningkatkan kualitas pendidikan. Dosen yang profesional mempunyai peran ganda, yaitu senantiasa memelihara dan mengembangkan profesionalisme dalam bidang keilmuan dan keahliannya, sekaligus mampu memahami dan meningkatkan kepuasan layanan akademiknya bagi mahasiswa. Penelitian ini bertujuan menganalisis tingkat profesionalitas dosen dalam perkuliahan; menganalisis tingkat kepuasan mahasiswa dalam layanan akademik; dan menganalisis pengaruh tingkat profesionalitas dosen dalam perkuliahan terhadap kepuasan mahasiswa atas layanan akademik pada program studi pendidikan ekonomi STKIP Nurul Huda Oku Timur. Penelitian ini merupakan penelitian kuantitatif dengan rancangan penelitian survey, memberikan kuesioner kepada responden. Populasi 270 dan sampel 135 mahasiswa. Teknik pengambilan sampel dengan startifield proportional random sampling. Data dianalisa dengan analisis regresi linear sederhana, dengan menggunakan bantuan microsoft excel windows 10. Tingkat profesionalitas dosen adalah sedang dalam memberikan perkuliahan dengan diperoleh persentase hasil instrumen 67,41\%, dan kepuasan mahasiswa atas layanan akademik yang diberikan dosen adalah sedang dengan diperoleh persentase hasil instrumen $60,00 \%$. Berdasarkan hasil analisis data secara parsial diperoleh thitung sebesar 11,249 dan ttabel sebesar1,656 maka Ho ditolak dan Ha diterima. Sehingga terdapat pengaruh yang cukup signifikan antara profesionalitas dosen dalam perkuliahan terhadap kepuasan mahasiswa atas layanan akademik.
\end{abstract}

Kata Kunci:Profesionalitas Dosen, Kepuasan Mahasiswa, Layanan Akademik

\section{PENDAHULUAN}

Kualitas kehidupan bangsa sangat ditentukan oleh faktor pendidikan, peranan pendidikan sangat penting untuk menciptakan kehidupan yang cerdas, damai, terbuka, dan demokratis, oleh karenanya tuntutan pembaharuan pendidikan harus selalu dilakukan untuk meningkatkan kualitas pendidikan nasional yaitu pendidikan harus adaptif terhadap perubahan zaman, yang diharapkan dapat menaikkan harkat dan martabat manusia Indonesia. Dalam dunia pendidikan tinggi dewasa ini, peran dan tanggung jawab dosen sangat menentukan dalam mewujudkan tercapainya tujuan pendidikan yaitu 
mencerdaskan kehidupan bangsa, meningkatkan kualitas manusia Indonesia yang meliputi kualitas iman atau takwa, menguasai IPTEK dan seni.

Menurut UU No. 14 tahun 2005 tentang Guru dan Dosen, dalam pasal 1, disebutkan bahwa dosen sebagai pendidik profesional dan ilmuan dengan tugas inti mentransformasikan, mengembangkan dan menyebarluaskan ilmu pengetahuan, teknologi, dan seni melalui pendidikan, penelitian dan pengabdian kepada masyarakat. Mutu/kualitas lulusan sangat dipengaruhi oleh beberapa faktor, salah satunya faktor yang mempengaruhi adalah kualitas pengajaran. Dosen ibarat mesin penggerak bagi segala hal yang berhubungan dengan aktivitas ilmiah dan akademis yang tugas serta tanggung jawab yang diembannya cukup berat dalam rangka mewujudkan salah satu tujuan nasional yaitu mencerdaskan kehidupan bangsa (generasi muda) sebagai penerus bangsa. Seorang dosen harus benar-benar mampu mengembangkan profesionalisme kinerjanya dilengkapi dengan loyalitas yang tinggi. Tugas yang harus dijalankan cukup kompleks meliputi persiapan sebelum perkuliahan, pelaksanaan perkuliahan dan evaluasi pembelajaran/perkuliahan. Persiapan yang dilakukan antara lain: membuat perencanaan pembelajaran berupa silabus, RPP, kontrak perkulaihan, materi dan alat yang akan digunakan dalam perkuliahan, mengajar atau memberi kuliah, menilai serta mendidik, dan motivator bagi mahasiswa. Penilaian sebagai dosen profesional dalam melakukan tugas harus memenuhi seperangkat pengetahuan, keterampilan, perilaku dan kepribadian yang kompeten yaitu meliputi: 1) Kompetensi pedagogik, 2) Kompetensi kepribadian, 3) Kompetensi sosial dan 4) Kompetensi profesional.

Sekolah Tinggi Keguruan dan Ilmu Pendidikan (STKIP) Nurul Huda sebagai satuan pendidikan, penyelenggara pendidikan tinggi memiliki tugas utama yakni menghasilkan sumber daya manusia (SDM) berkualitas. Dalam upaya tersebut, hasil lulusan dari pendidikan tinggi dipengaruhi oleh kualitas sumber daya manusia pengelola terutama adalah tenaga pendidik yaitu dosen. Selain tenaga pendidik yaitu dosen, STKIP sebagai institusi penyedia layanan pendidikan tinggi, harus senantiasa mengutamakan kepuasan mahasiswa sebagai pelanggan dengan memberikan pelayanan terbaik. Beberapa bidang pelayanan yang harus dikembangkan secara berkelanjutan meliputi: kurikulum program studi, proses pembelajaran, sumber daya manusia yaitu dosen, pegawai, dan tenaga kependidikan operator, mahasiswa, sarana dan prasarana, suasana akademik, penelitian serta publikasi, pengabdian kepada masyarakat, 
Pengaruh Profesionalitas Dosen Dalam Perkuliahan Terhadap Kepuasan Mahasiswa Atas Layanan Akademik Pada Program Studi Pendidikan Ekonomi STKIP Nurul Huda Sukaraja

manajemen lembaga, sistem informasi, dan kerjasama dalam/luar negeri. Pelayanan akademik yang baik dapat membentuk citra positif bagi STKIP sebagai salah satu perguruan Tinggi swasta terkemuka penyedia layanan program sarjana.

Untuk mewujudkan Perguruan Tinggi yang bermutu, diperlukan lembaga pendidikan yang dapat menggerakkan semua stakeholder pendidikan untuk bersama-sama merencanakan dan menggagas visi, misi, lembaga pendidikan untuk kemudian secara bersama-sama pula merealisasikannya, sehingga terwujud lembaga pendidikan yang bermutu yang menjadi harapan semua pihak. Profesionalitas dosen, dapat dilihat dari kompetensi yang dimiliki seorang dosen. Kompetensi tersebut dapat dilihat ketika kegiatan pembelajaran di dalam kelas maupun di luar kelas. Dalam kegiatan pembelajaran dosen tidak memahami pengelolaan kelas sehingga mahasiswa tidak memperhatikan materi yang dijelaskan, proses pembelajaran yang monoton dengan metode dan media yang sama tiap hari sehingga banyak mahasiswa yang bosan dikelas, dosen kurang menunjukkan semangat dalam kegiatan pembelajaran, kurang memberikan motivasi mahasiswa untuk lebih aktif dalam kegiatan pembelajaran dikelas, dan dosen tidak memberikan penguatan terhadap materi yang didiskusikan oleh mahasiswa.

Berdasarkan observasi awal peneliti, dengan melakukan wawancara mahasiswa program studi pendidikan ekonomi terdapat beberapa masalah sebagai berikut : Dosen datang tidak tepat waktu, menggunakan media pembelajaran yang tidak bervariasi sehingga pembelajaran didalam kelas menjadi membosankan dan pembelajaran menjadi tidak kondusif, penguasaan materi yang dirasa mahasiswa kurang baik, dan dosen kurang memberikan penguatan/apresiasi terhadap respon mahasiswa ketika kegiatan pembelajaran didalam kelas.

\section{METODE}

Penelitian ini merupakan penelitian kuantitatif dengan rancangan penelitian survey, dengan memberikan kuesioner kepada responden untuk memperoleh data pada suatu saat tertentu (data are gathered just once) yang menanyakan mengenai beberapa aspek terkait dengan variabel yang diteliti, tanpa melakukan perlakuan apapun terhadap responden. Populasi dalam penelitian bukan hanya orang, tetapi juga obyek dan benda-benda alam yang 
lain. Populasi juga meliputi seluruh karakteristik/sifat. Menurut Sugiyono (2017:7) "Metode ini disebut metode kuantitatif karena data penelitian berupa angka-angka dan analisis menggunakan statistik".

Tabel 1

Populasi Penelitian

\begin{tabular}{|c|c|c|}
\hline No. & Semester & Jumlah Mahasiswa \\
\hline 1 & VI & 60 \\
\hline 2 & IV & 102 \\
\hline 3 & II & 108 \\
\hline & Jumlah & $\mathbf{2 7 0}$ \\
\hline
\end{tabular}

Sumber: Dokumentasi STKIP Nurul Huda Sukaraja

Sampel dalam penelitian ini berjumlah 135 mahasiswa. Pengambilan sampel menggunakan Proportionate Stratifield Random Sampling yaitu pengambilan sampel dari anggota populasi secara acak dan berstrata secara profesional, dilakukan sampling ini apabila anggota populasinya tidak heterogen atau tidak sejenis, (Sugiyono, 2017:82). Alat pengumpulan data dalam penelitian ini adalah angket.

Tabel 2

Penentuan Jumlah Sampel Penelitian

\begin{tabular}{|c|c|c|c|}
\hline \multirow{2}{*}{$\mathbf{N}$} & \multicolumn{3}{|c|}{ Signifikasi } \\
\cline { 2 - 4 } & $\mathbf{1 \%}$ & $\mathbf{5 \%}$ & $\mathbf{1 0 \%}$ \\
\hline $\mathbf{2 5 0}$ & 182 & 146 & 130 \\
\hline $\mathbf{2 6 0}$ & 187 & 149 & 133 \\
\hline $\mathbf{2 7 0}$ & 192 & 152 & $\mathbf{1 3 5}$ \\
\hline
\end{tabular}

(Sugiyono, 2017:87)

Penelitian ini menggunakan angket tertutup untuk mengetahui data profesionalitas dosen dalam perkuliahan terhadap kepuasan mahasiswa atas layanan akademik. Sedangkan pengukuran angket dalam penelitian ini menggunakan skala likert. Skala likert adalah skala yang dapat digunakan untuk mengukur sikap, pendapat, persepsi seseorang, untuk mengukur suatu objek atau fenomena sosial (Sugiyono, 2017:93-94). Adapun angket dalam penelitian ini berjumlah 20 pernyataan untuk variabel profesionalitas dosen dalam perkuliahan dan 10 pernyataan untuk variabel kepuasan mahasiswa atas layanan akademikyang diberi skor 5,4,3,2,1. 
Pengaruh Profesionalitas Dosen Dalam Perkuliahan Terhadap Kepuasan Mahasiswa Atas Layanan Akademik Pada Program Studi Pendidikan Ekonomi STKIP Nurul Huda Sukaraja

\section{TEKNIK ANALISIS DATA}

Metode kuantitatif adalah metode analisis data yang menggunakan perhitungan ilmu statistik.

1) Metode Analisis Deskriptif Persentase

Analisis ini digunakan untuk mengetahui seberapa besar pengaruh variabel profesionalitas dosen dalam perkuliahan berpengaruh terhadap kepuasan mahasiswa atas layanan akademik. Statistik deskriptif adalah statistik yang digunakan untuk menganalisis dengan cara mendeskripsikan atau menggambarkan data yang telah terkumpul sebagaimana adanya tanpa bermaksud membuat kesimpulan yang berlaku untuk umum atau generalisasi (Sugiyono, 2013:207-208). Rumus yang digunakan adalah sebagai berikut :

$$
\mathrm{DP}(\%)=\frac{n}{N} \times 100 \%
$$

Keterangan:

DP atau \% : Deskriptif persentase

$\mathrm{n}$ : Nilai yang diperoleh

$\mathrm{N}$ : Jumlah seluruh nilai

\section{2) Analisis Regresi Sederhana}

Dalam penelitian ini penulis menggunakan teknik analisis data regresi linier sederhana. Sebelum pengujian hipotesis perlu dilakukan perhitungan rata-rata, standar deviasi dan kategori tinggi sedang rendah. Persamaan umum regresi linier sederhana di rumuskan sebagai berikut:

$$
\begin{aligned}
& \mathrm{Y}^{\curvearrowleft}=\mathrm{a}+\mathrm{b} \overline{\mathrm{X}} \\
& a=\frac{\sum Y-B \sum X}{n} \\
& b=\frac{n \sum X Y-\left(\sum X\right)\left(\sum Y\right)}{n \sum X^{2}-\left(\sum X\right)^{2}}
\end{aligned}
$$$$
\text { Sumber : Sugiyono (2017: 261) }
$$

Keterangan:

$a=$ intersep

$b=$ koefisien regresi

$n=$ sampel penelitian

$\mathrm{X}=$ variabel bebas

$\mathrm{Y}=$ variabel terikat

$\overline{\mathrm{X}}=$ rata-rata variabel independen

1. Rata-rata

Rata-rata hitung (mean) dapat dirumuskan sebagai berikut: 


$$
\begin{aligned}
& \bar{x}=\frac{\sum X}{N} \\
& \quad \text { Keterangan: } \\
& \bar{x}=\text { mean (rata-rata) } \\
& \sum X=\text { jumlah variabel } \mathrm{x} \\
& N=\text { jumlah responden } / \text { siswa }
\end{aligned}
$$

2. Standar Deviasi

$$
\begin{aligned}
& s^{2}=\sqrt{\frac{n \cdot\left(\sum x^{2}\right)-\left(\sum x\right)^{2}}{n(n-1)}} \\
& S^{2}=\text { Keterangan: } \\
& \sum X=\text { jumlar deviasi } \\
& n=\text { banyaknyabel } \mathrm{x}
\end{aligned}
$$

3) Uji Prasyarat Hipotesis

Untuk melakukan pengujian hipotesis syarat yang harus dipenuhi dalam menggunakan statistik parametris adalah data tersebut harus memenuhi syarat normalitas. Uji normalitas dimaksudkan untuk mengetahui apakah sampel berasal dari populasi yang terdistribusi normal atau tidak. Uji normalitas dalam penelitian ini menggunakan rumus $Z_{\text {kurtosis }}$ dan $Z_{\text {skewness }}$ dengan rumus dan ketentuan sebagai berikut:

$$
\begin{aligned}
& Z_{\text {Kurtosis }}=\frac{\text { Kurtosis }}{\sqrt{24 / \mathrm{n}}} \\
& Z_{\text {Skewness }}=\frac{\text { Skewness }}{\sqrt{6 / \mathrm{n}}}
\end{aligned}
$$

Dengan ketentuan untuk $\alpha=0,05$ jika $-1,96<Z_{\text {kurtosis }}<1,96$ berarti data memiliki distribusi normal dan jika $-1,96<\mathrm{Z}$ skewness $<1,96$ berarti data memiliki distribusi normal.

4) Uji Hipotesis

Dalam penelitian ini, pengujian hipotesis menggunakan uji t dapat dilakukan dengan menggunakan rumus sebagai berikut:

$$
t=\frac{r \sqrt{n-2}}{\sqrt{1-r^{2}}} \quad \text { (Sugiyono, 2017: 184) }
$$

Keterangan:

$t=$ nilai $\mathrm{t}$ hitung 
Pengaruh Profesionalitas Dosen Dalam Perkuliahan Terhadap Kepuasan Mahasiswa Atas Layanan Akademik Pada Program Studi Pendidikan Ekonomi STKIP Nurul Huda Sukaraja

$$
\begin{aligned}
& r=\text { besarnya koefisien } \\
& n=\text { jumlah sampel }
\end{aligned}
$$

\section{HASIL DAN PEMBAHASAN}

\section{Hasil}

Hasil penelitian menunjukkan bahwa iklan pada Mahasiswa Progam Studi Pendidikan Universitas Batanghari berada dalam kategori tinggi dengan nilai mean sebesar 58.90 dengan nilai maksimum 69 dan nilai minimum 48, kelompok referensi berada pada kategori tinggi dengan nilai mean sebesar 34.88 dengan nilai maksimum 44 dan nilai minimum 28, dan perilaku konsumsi berada pada kategori tinggi dengan nilai mean sebesar 77.39 dengan nilai maksimum 91 dan nilai minimum 64 yang di artikan memiliki perilaku konsumsi mengarah pada perilaku konsumtif.

Uji asumsi klasik yang dilakukan pada penelitian ini yaitu uji normalitas menggunakan grafik P-P Plot of Regression Standardized Residual bahwa penelitian ini berdistribusi normal. Hal ini ditunjukkan dengan data menyebar di sekitar garis diagonal dan mengikuti arah garis diagonal. Kemudian uji multikolinieritas dapat dilihat dari nilai VIF (Variance Inflation Factor) dan nilai Tolerance, bahwa pada penelitian ini tidak terjadi multikolinieritas dilihat dari variabel bebas memiliki nilai VIF sebesar $1.752>10$ atau nilai Tolerance sebesar $0.571<10$. Selanjutnya uji heterokedastisitas yang dilihat dari nilai Sig. variabel iklan sebesar $0.962>0.05$ dan variabel kelompok referensi sebesar $0.889>0.05$, sehingga disimpulkan model regresi tidak terjadi heterokedastisitas.

\section{a. Hipotesis statistik pengaruh iklan terhadap perilaku konsumsi}

Tabel 1

\section{Uji Parsial Iklan}

\begin{tabular}{|c|c|c|c|c|c|}
\hline \multirow[b]{2}{*}{ Model } & \multicolumn{2}{|c|}{$\begin{array}{c}\text { Unstandardized } \\
\text { Coefficients }\end{array}$} & \multirow{2}{*}{$\begin{array}{c}\text { Standardized } \\
\text { Coefficients } \\
\text { Beta }\end{array}$} & \multirow[b]{2}{*}{$\mathrm{t}$} & \multirow[b]{2}{*}{ Sig. } \\
\hline & $\mathrm{B}$ & Std. Error & & & \\
\hline $1 \quad$ (Constant) & 27.434 & 6.679 & & 4.108 & .000 \\
\hline Iklan & .808 & .122 & .696 & 6.649 & .000 \\
\hline
\end{tabular}

Coefficients $^{\mathrm{a}}$

a. Dependent Variable: Perilaku Konsumsi

Berdasarkan hasil perhitungan dalam tabel di atas menunjukkan bahwa terdapat pengaruh iklan terhadap perilaku konsumsi sebesar 0.696, dengan 
nilai signifikansi 0.000. Dengan persamaan $\mathrm{Y}=\mathrm{a}+\mathrm{bX} \mathrm{X}_{1}+\mathrm{e}$, atau $\mathrm{Y}=27.434+0.696 \mathrm{X}_{1}+\mathrm{e}$, yang berarti setiap penambahan iklan sebesar 1 maka akan berpengaruh pada kenaikan perilaku konsumsi sebesar 0.696. Dapat diketahui hasil Uji t sebesar 6.649 sedangkan $t_{\text {tabel }}$ sebesar 1.677 maka $6.649>1.677$ berarti terdapat pengaruh iklan terhadap perilaku konsumsi.

\section{b. Hipotesis statistik pengaruh kelompok referensi terhadap perilaku konsumsi}

Tabel 2

Uji Parsial Kelompok Referensi

Coefficients $^{\mathrm{a}}$

\begin{tabular}{|c|c|c|c|c|c|}
\hline \multirow[b]{2}{*}{ Model } & \multicolumn{2}{|c|}{$\begin{array}{c}\text { Unstandardized } \\
\text { Coefficients }\end{array}$} & \multirow{2}{*}{$\begin{array}{c}\text { Standardized } \\
\text { Coefficients }\end{array}$} & \multirow[b]{2}{*}{ 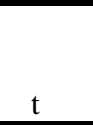 } & \multirow[b]{2}{*}{ Sig. } \\
\hline & $\mathrm{B}$ & Std. Error & & & \\
\hline $1 \quad$ (Constant) & 31.484 & 6.332 & & 4.972 & .000 \\
\hline $\begin{array}{l}\text { Kelompok } \\
\text { Referensi }\end{array}$ & 1.225 & .192 & .681 & 6.378 & .000 \\
\hline
\end{tabular}

a. Dependent Variable: Perilaku Konsumsi

Berdasarkan hasil perhitungan dalam tabel di atas menunjukkan bahwa terdapat pengaruh kelompok referensi terhadap perilaku konsumsi sebesar 0.681, dengan nilai signifikansi 0.000. Dengan persamaan $\mathrm{Y}=\mathrm{a}+\mathrm{bX} 2+\mathrm{e}$, atau $\mathrm{Y}=31.484+0.681 \mathrm{X}_{2}+\mathrm{e}$, yang berarti setiap penambahan kelompok referensi sebesar 1 maka akan berpengaruh pada kenaikan perilaku konsumsi sebesar 0.681. Dapat diketahui hasil Uji t sebesar 6.378 sedangkan $t_{\text {tabel }}$ sebesar 1.677 maka $6.378>1.677$ berarti terdapat pengaruh kelompok referensi terhadap perilaku konsumsi.

\section{c. Hipotesis statistik pengaruh secara simultan iklan dan kelompok referensi terhadap perilaku konsumsi}

Tabel 3

\section{Uji Simultan Iklan dan Kelompok Referensi}

Model Summary ${ }^{\mathrm{b}}$

\begin{tabular}{|c|c|c|c|c|c|}
\hline Model & $\mathrm{R}$ & R Square & $\begin{array}{c}\text { Adjusted R } \\
\text { Square }\end{array}$ & $\begin{array}{c}\text { Std. Error of the } \\
\text { Estimate }\end{array}$ & Durbin-Watson \\
\hline 1 & $.757^{\mathrm{a}}$ & .573 & .555 & 6.267280 & 1.906 \\
\hline
\end{tabular}

a. Predictors: (Constant), Kelompok Referensi, Iklan

b. Dependent Variable: Perilaku Konsumsi

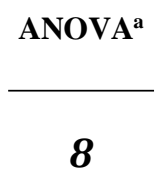


Pengaruh Profesionalitas Dosen Dalam Perkuliahan Terhadap Kepuasan Mahasiswa Atas Layanan Akademik Pada Program Studi Pendidikan Ekonomi STKIP Nurul Huda

Sukaraja

\begin{tabular}{|l|r|r|r|r|c|}
\hline Model & Sum of Squares & \multicolumn{1}{c|}{ df } & Mean Square & F & Sig. \\
\hline Regression & 2428.612 & 2 & 1214.306 & 30.915 & $.000^{\mathrm{b}}$ \\
Residual & 1806.825 & 46 & 39.279 & & \\
Total & 4235.437 & 48 & & & \\
\hline
\end{tabular}

a. Dependent Variable: Perilaku Konsumsi

b. Predictors: (Constant), Kelompok Referensi, Iklan

Berdasarkan hasil perhitungan dalam tabel di atas menunjukkan bahwa terdapat pengaruh secara simultan iklan dan kelompok referensi terhadap perilaku konsumsi sebesar 0.757 pada signifikansi sebesar 0.000 atau dapat dilihat pada nilai $\mathrm{F}_{\text {hitung }}$ sebesar $30.915>3.20$.

\section{Tabel 4}

Uji Regresi Berganda

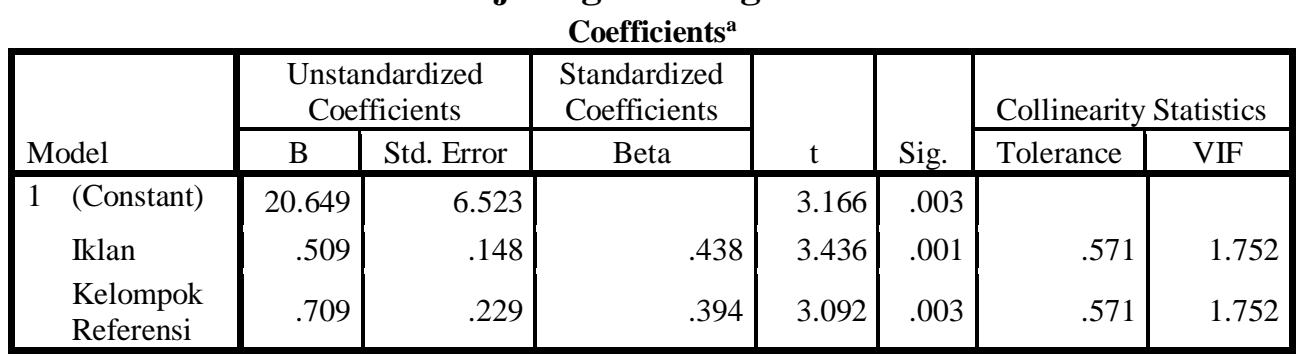

a. Dependent Variable: Perilaku Konsumsi

Berdasarkan hasil perhitungan dalam tabel di atas maka dapat disusun persamaan regresi berganda yaitu $\mathrm{Y}=\alpha_{0}+\mathrm{b}_{1 \times 1}+\mathrm{b}_{2 \times 2}+\mathrm{e}$ yaitu $\mathrm{Y}=20.649+$ $0.509 \mathrm{X}_{1}+0.709 \mathrm{X}_{2}+$ e. Model persamaan regresi berganda tersebut dapat menjelaskan bahwa, apabila variabel bebas yaitu iklan mengalami kenaikan sebesar 1 maka akan diikuti dengan kenaikan perilaku konsumsi sebesar 0.509 satuan. Sedangkan apabila variabel bebas kelompok referensi mengalami kenaikan sebesar 1 maka akan diikuti dengan kenaikan perilaku konsumsi sebesar 0.709 satuan.

\section{Pembahasan}

Berdasarkan hasil penelitian diketahui bahwa iklan merupakan media yang sering digunakan oleh mahasiswa sebelum memutuskan untuk berkonsumsi. Mahasiswa sebagian besar sering memanfaatkan media iklan untuk mencari informasi keunggulan produk. Hal ini terlihat dari analisis deskriptif iklan berada pada kategori tinggi. Iklan memberikan pengaruh dalam perilaku konsumsi mahasiswa yang mengarahkan pada perilaku 
konsumtif mahasiswa. Hal ini terlihat dari intensitas mahasiswa dalam melihat iklan lebih dari 6 kali dalam sehari. Pemilihan media iklan yang tepat dengan tampilan yang menarik membuat mahasiswa mudah terpengaruh untuk membeli produk yang ditampilkan dalam iklan. Selain itu iklan yang ditampilkan memberikan daya tarik terhadap keunggulan produk ditambah lagi iklan yang memberikan penawaran khusus seperti diskon, sale, dan doorprice yang membuat mahasiswa terdorong untuk melakukan pembelian tanpa melihat penting tidaknya produk tersebut.

Menurut Morissan (2010) iklan merupakan salah satu bentuk promosi yang paling dikenal dan paling banyak dibahas orang, hal ini kemungkinan karena daya jangkauannya yang luas. Terlebih lagi saat ini iklan dapat dengan mudah dilihat dalam media online. Jangkauan media onlineyang sangat luas dapat dengan mudah dijangkau oleh masyarakat luas khususnya pada mahasiswa, karena sebagian besar mahasiswa sudah memiliki smartphone yang memiliki fitur-fitur aplikasi media online yang menawarkan beragam jenis produk yang selalu uptodate. Penelitian ini sejalan dengan penelitian yang dilakukan oleh Wulandari dkk (2016) iklan mempunyai persentase tertinggi terhadap perilaku konsumsi siswa, dapat dilihat dari perilaku siswa yang terpengaruh membeli suatu produk baru yang diiklankan oleh produsen baik itu melalui media cetak maupun media elektronik.

Iklan dalam penelitian ini memberikan pengaruh positif kepada perilaku konsumsi, semakin mahasiswa tertarik untuk membeli suatu produk yang dipengaruhi oleh rasa ingin tahu yang tinggi serta mengikuti trend yang sedang booming maka semakin mudah mahasiswa terpengaruh iklan dalam berkonsumsi sehingga ada keinginan untuk membeli produk yang diiklankan, hal tersebut akan mengarahkan pada perilaku konsumtif. Perilaku konsumtif begitu dominan dikalangan remaja (Sumartono, 2002). Sifat-sifat remaja dalam hal ini mahasiswa yang cenderung mudah terbujuk rayuan iklan terutama iklan yang memberikan keunggulan serta tampilan yang menarik atas suatu produk, sifat tidak realistis dan cenderung boros dalam menggunakan uang sakunya. Hal ini mendukung teori yang dikemukakan oleh Kertamukti (2015) dari sekian banyak iklan yang ada tujuannya adalah sama yaitu mendekati khalayak sasaran mereka serta mengajak khalayak untuk membeli atau menggunakan produk atau jasa yang mereka tawarkan. 
Pengaruh Profesionalitas Dosen Dalam Perkuliahan Terhadap Kepuasan Mahasiswa Atas Layanan Akademik Pada Program Studi Pendidikan Ekonomi STKIP Nurul Huda

Sukaraja

Iklan selalu menampilkan sisi keunggulan suatu produk yang dikemas sedemikian rupa sehingga menarik konsumen untuk tertarik membeli atau menggunakan produk tersebut yang diiklankan. Hal inilah yang membuat mahasiswa Prodi Pendidikan Ekonomi Universitas Jambi seringkali terbujuk oleh tawaran produk yang terdapat dalam ikan.

Kelompok referensi berpengaruh terhadap perilaku konsumsi mahasiswa, hal ini telihat dari sebagian besar mahasiswa menjadikan kelompok referensi sebagai rujukan dalam perilaku konsumsinya. Kelompok referensi dalam penelitian ini merujuk pada publik figur yang menjadi referensi mahasiswa dalam berkonsumsi. Menurut Peter dan Olson (2000) kelompok referensi melibatkan satu atau lebih orang yang dijadikan sebagai dasar pembanding atau titik referensi dalam membentuk tanggapan atau afeksi dan kognisi serta menyatakan perilaku seseorang. Dalam penelitian ini kelompok referensi berada dalam kategori tinggi yang dan berpengaruh positif terhadap perilaku konsumsi mahasiswa. Hal ini berarti apabila semakin tinggi pengaruh kelompok referensi dalam keputusan berkonsumsi, maka semakin tinggi pula perilaku konsumsi mahasiswa yang mengarahkan pada perilaku konsumtif.

Pola perilaku konsumtif memiliki beberapa indikator yaitu: 1) membeli produk karena iming-iming hadiah, 2) membeli produk karena kemasannya menarik, 3) membeli produk demi menjaga penampilan gengsi, 4) membeli produk berdasarkan pertimbangan harga (bukan atas dasar manfaat), 5) membeli produk hanya sekedar manjaga simbol dan status, 6) memakai produk karena unsur konformitas terhadap model yang mengiklankan produk, 7) munculnya penilaian bahwa membeli produk dengan harga mahal akan menimbulkan rasa percaya diri, 8) keinginan mencoba lebih dari dua produk sejenis berbeda (Sumartono, dalam Sukari, dkk: 2013). Karena itulah munculnya perilaku konsumtif dalam berkonsumsi. Mahasiswa cenderung membeli suatu produk barang atau jasa karena dorongan nafsu dan pengaruh dari lingkungan salah satunya kelompok referensi yang ada di dalam iklan.

Kelompok referensi menjadi acuan mahasiswa dalam berkonsumsi yaitu memberikan informasi dan membentuk kepercayaan mahasiswa terhadap suatu produk yang ditawarkan atau yang digunakannya. Sebelum memutuskan untuk membeli suatu produk biasanya mahasiswa mencari terlebih dahulu kelompok referensi atau publik figur yang menggunakan produk tersebut. 
Selain untuk mendapatkan hasil yang memuaskan sesuai dengan keinginan, mahasiswa juga merasa bangga jika membeli produk sama dengan yang digunakan publik figur idolanya. Hasil penelitian ini mendukung penelitian yang dilakukan oleh Fitriyah (2013) kelompok acuan berpengaruh signifikan terhadap keputusan pembelian batik tulis Jetis pada toko Amri Jaya Sidoarjo, artinya kelompok acuan baik secara langsung maupun tidak langsung memberikan dorongan bagi konsumen untuk membeli batik tulis Jetis.

Dari hasil temuan dilapangan pemanfaatan smartphone yang dimiliki mahasiswa lebih sering digunakan untuk mencari tahu informasi tentang mode fashion yang sedang hits saat ini, khususnya pada kalangan wanita. Mahasiswa sering menggunakan smartphone untuk membuka aplikasi instagram, yang didalamnya banyak menawarkan iklan produk fashion yang sedang hits. Mahasiswa cenderung membuka toko-toko online dan mengikuti artis atau publik figur yang menjadi referensi dalam berkonsumsi. Tawaran dari iklan dan publik figur inilah yang mempengaruhi perilaku konsumsi mahasiswa. Sehingga mahasiswa cenderung tidak rasional dalam berkonsumsi karena mengikuti tren dari publik figur yang menawarkan produk-produk yang menarik.

\section{SIMPULAN}

Berdasarkan hasil penelitian, maka kesimpulan yang dapat ditarik dari penelitian ini adalah terdapat pengaruh kuat dan signifikan iklan terhadap perilaku konsumsi mahasiswa Progam Studi Pendidikan Ekonomi Universitas Batanghari. Perilaku konsumsi yang dipengaruhi iklan mengarahkan pada perilaku konsumtif. Mahasiswa cenderung terpengaruh ikan dalam berkonsumsi, karena iklan menawarkan beragam produk yang dibutuhkan oleh mahasiswa. Selain itu informasi, penempatan dan media yang digunakan dalam iklan membuat mahasiswa tertarik untuk melakukan pembelian atas produk yang diiklankan. Karena sebagian besar mahasiswa memiliki smartphone yang memiliki aplikasi media online yang memberikan beragam jenis pilihan barang konsumsi yang akan mempengaruhi perilaku konsumsinya.

Terdapat pengaruh kuat dan signifikan kelompok referensi terhadap perilaku konsumsi mahasiswa Progam Studi Pendidikan Ekonomi Universitas Batanghari. Kelempok referensi memberikan pengaruh mahasiswa dalam 
Pengaruh Profesionalitas Dosen Dalam Perkuliahan Terhadap Kepuasan Mahasiswa Atas Layanan Akademik Pada Program Studi Pendidikan Ekonomi STKIP Nurul Huda

Sukaraja

berkonsumsi produk barang dan jasa karena publik figur yang mereka lihat dapat memberikan informasi tentang suatu produk yang akan dikonsumsi. Selain itu kelompok referensi memberikan pengaruh terhadap kepercayaan diri mahasiswa yang menggunakan produk sama seperti dengan yang digunakan publik figur atau kelompok referensinya.

\section{SARAN}

Saran yang penulis berikan bagi pihak (1) Produsen atau pemasar yaitu memberikan informasi yang menarik tentang suatu produk yang ditawarkan agar konsumen merasa yakin bahwa produk tersebut adalah produk yang tepat. Selain itu produsen harus terus meningkatkan kretivitas dan inovasi produk untuk memenuhi permintaan konsumen yang semakin kritis terhadap pemilihan suatu produk; (2) Mahasiswa agar dapat menjadi rujukan dalam berperilaku konsumsi yang baik, iklan dan kelompok referensi yang berpengaruh dalam membeli suatu produk dapat digunakan dengan baik untuk mencari informasi dan keunggulan suatu produk agar mahasiswa tidak mudah terbujuk rayuan iklan dan kelompok referensinya; (3) Peneliti lain dapat dijadikan masukan ataupun menambah rujukan untuk penelitian selanjutnya yang terkait dengan iklan dan kelompok referensi terhadap perilaku konsumsi sehingga berguna sebagai tambahan pengetahuan, kajian dan referensi untuk permasalahan yang terkait dengan masalah dalam penelitian ini. Selanjutnya bagi peneliti lain untuk dapat memperluas variabel lain diluar variabel yang digunakan dalam penelitian ini.

\section{UCAPAN TERIMAKASIH}

Ucapan terimakasih ditujukan kepada Fakultas Keguruan dan Ilmu Pendidikan Progam Studi Pendidikan Ekonomi Universitas Batanghari Jambi, Tim Jurnal Utility STKIP Nurul Huda.

\section{REFERENSI}

Alfiani, A. 2016. Kepuasan Mahasiswa Terhadap Pelayanan Administrasi Akademik Di Subbag . Skripsi. Fakultas Ilmu Pendidikan : Universitas Negeri Yogyakarta 
Chairunnisa, C. 2015. Hubungan Tata Kelola Universitas Dan Profesionalitas

Dosen, Dengan Mutu Layanan Pendidikan. Jurnal: Universitas Muhammadiyah Jakarta.Vol 2 No 3 Hal 184-197

Lidya, M dan Wahyu H. 2015. Pengaruh Kualitas Pelayanan Akademik Terhadap Kepuasan Mahasiswa Di Politeknik Negeri Batam. Jurnal: Politeknik Negeri Batam

Rahareng, V. dan Nurnida R.2017. Pengaruh Kualitas Pelayanan Akademik Terhadap Kepuasan Mahasiswa. Jurnal:Universitas Telkom.Vol 2 No 2 Hal 125-133

Rinala, I . 2013. Pengaruh Kualitas Pelayanan Akademik TerhadapKepuasan Dan Loyalitas Mahasiswa Pada Sekolah Tinggi Pariwisata Nusa Dua Bali. Jurnal: Universitas Pendidikan Ganesha Singaraja, Indonesia. Vol 4

Susanto, H. 2014. Pengaruh Layanan Akademik Terhadap Kepuasan Mahasiswa Program Pascasarjana Universitas Terbuka Pada Unit Program Belajar Jarak Jauh (UPBJJ) Mataram.Jurnal:Universitas Terbuka Mataram. Vol 15 No 2 Hal 88-98

Sugiyono. 2017. Metodologi Penelitian Pendidikan Kuantitatif, Kualitatif, dan $R \& D$. Bandung. Alfabeta

Sugiyono. 2016. Statistika Untuk Penelitian. Bandung. Alfabeta

UU Republik Indonesia no.14 Tahun 2005 tentang guru dan dosen. Bandung : Citra Umbara 